\title{
Relevance of IgE to novel kiwi seed allergens evaluated in kiwi allergic children
}

\author{
Hillevi Englund ${ }^{1 *}$, Johanna Hidman', Otti Bengtsson-Gref ${ }^{1}$, Caroline Nilsson², Peter Brostedt ${ }^{1}$ \\ From Food Allergy and Anaphylaxis Meeting 2014 \\ Dublin, Ireland. 9-11 October 2014
}

\section{Background}

Kiwi fruit is a common food allergen and severe allergic reactions are observed. The current diagnostic accuracy is poor with a reported diagnostic sensitivity of $65 \%$ in a large European cohort. Recently, two new kiwi allergens were registered, both being storage proteins and both isolated from kiwi seeds. Storage proteins are often linked to severe clinical reactions in other food allergies. The aim of this study was to evaluate sera from Swedish children with documented kiwi allergy, and investigate their IgE-reactivity to purified seed allergens.

\section{Methods}

Kiwi seeds were isolated, extracted and analyzed using chromatographic methods, MALDI-TOF and SDSPAGE. Patient samples from children with documented primary kiwi allergy were used for evaluation. Care was taken to not include patients primarily sensitized to birch pollen in this study, to avoid cross-reactivity between Bet $\mathrm{v} 1$ and the homologous Act d 8. IgEimmunoreactivity towards all four purified proteins, as well as the whole kiwi seed extract, was studied.

\section{Results}

$2 \mathrm{~S}$ albumin (Act d 13), $11 \mathrm{~S}$ globulin (Act d 12), 7S globulin, and LTP (Act d 10) were purified from kiwi seeds and protein identities were confirmed by MALDI-TOF (Act d 10 and Act d 12), gelfiltration and SDS-PAGE. Levels of allergen-specific IgE in patients' sera were analyzed and differentiated IgE-binding patterns to the purified storage proteins were observed.

\section{Conclusion}

Swedish kiwi allergic children are sensitized to storage proteins isolated from kiwi seeds. Given the importance

${ }^{1}$ R\&D, ImmunoDiagnostic, Thermo Fisher Scientific, Uppsala, Sweden Full list of author information is available at the end of the article of IgE towards storage proteins in for example nuts, analyses of IgE-reactivity towards $11 \mathrm{~S}, 7 \mathrm{~S}$ and $2 \mathrm{~S}$ from kiwi seeds have the potential to lead to new insights in kiwi allergy and possibly improve the diagnostic accuracy of kiwi allergy tests.

\section{Authors' details}

${ }^{1}$ R\&D, ImmunoDiagnostic, Thermo Fisher Scientific, Uppsala, Sweden. ${ }^{2}$ Sach's Children's Hospital, Södersjukhuset, Stockholm, Sweden.

Published: 30 March 2015

doi:10.1186/2045-7022-5-S3-O24

Cite this article as: Englund et al:: Relevance of IgE to novel kiwi seed allergens evaluated in kiwi allergic children. Clinical and Translational Allergy 2015 5(Suppl 3):O24.

\section{Submit your next manuscript to BioMed Central and take full advantage of: \\ - Convenient online submission \\ - Thorough peer review \\ - No space constraints or color figure charges \\ - Immediate publication on acceptance \\ - Inclusion in PubMed, CAS, Scopus and Google Scholar \\ - Research which is freely available for redistribution

